\section{Response to: 'Diagnostic value of ultrasound halo count and Halo Score in giant cell arteritis: a retrospective study from routine care' by Molina Collada et al}

We would like to thank Molina Collada et $a l^{1}$ for their interest in our paper on the ultrasonographic Halo Score in giant cell arteritis (GCA). ${ }^{2}$ We welcome their effort to validate our findings.

The authors have performed a retrospective analysis of the Southend Halo Score and halo count in a GCA fast-track clinic. The authors report an excellent diagnostic accuracy of the Halo Score/halo count for a clinical diagnosis of GCA. The authors also observed a positive correlation between the Halo Score/halo count and systemic inflammation, that is, $\mathrm{C}$ reactive protein levels and the erythrocyte sedimentation rate (ESR). The correlation with ESR may reflect measurement by Westergren or a similar accurate method.

Thus, the study by Molina Collada et al is indeed the first to validate the feasibility and diagnostic performance of the Southend Halo Score in routine clinical care. Their findings confirm that the Halo Score may help to estimate the burden of inflammation in GCA. As previously stated, ${ }^{23}$ we agree with the authors that the Halo Score requires further validation. The utility of the Halo Score for the diagnosis, prognosis and monitoring of GCA disease activity is currently under investigation in prospective, multicentre studies (Halo Score for Giant Cell Arteritis (HAS-GCA) National Institute for Health Research Portfolio study \#264 294 and ClinicalTrials. gov, NCT03765788). The practicality of the Southend Halo Score and halo count, as recently discussed, ${ }^{4}$ could be an important advantage in this context. There is a need for an intrarater and inter-rater reliability exercise to validate these quantitative assessments, and this is planned for the eighth International Ultrasound Workshop on GCA, large-vessel vasculitis and polymyalgia rheumatica at Southend in March 2021.

\section{Kornelis SM van der Geest $\odot$, 1,2 Bhaskar Dasgupta $\odot^{2}$ \\ ${ }^{1}$ Rheumatology and Clinical Immunology, University Medical Center Groningen, University of Groningen, Groningen, Netherlands \\ ${ }^{2}$ Rheumatology, Southend University Hospital NHS Foundation Trust, Westcliff-on- Sea, UK}

Correspondence to Dr Bhaskar Dasgupta, Rheumatology, Southend University Hospital NHS Foundation Trust, Westcliff-on-Sea SSO ORY, UK; bhaskar.dasgupta@southend.nhs.uk
Handling editor Josef S Smolen

Twitter Bhaskar Dasgupta @profbdasgupta

Contributors KSMvdG and BD wrote the manuscript, revised it critically for important intellectual content and provided the final approval of the version published.

Funding The authors have not declared a specific grant for this research from any funding agency in the public, commercial or not-for-profit sectors.

Competing interests KSMvdG reports grants from the Mandema Stipend and the Dutch Society for Rheumatology, and personal fees from Roche outside the submitted work. BD reports grants and personal fees from Roche, and personal fees from GSK, BMS, Sanofi and AbbVie outside the submitted work.

Patient and public involvement Patients and/or the public were not involved in the design, conduct, reporting or dissemination plans of this research.

Patient consent for publication Not required.

Provenance and peer review Commissioned; internally peer reviewed.

(c) Author(s) (or their employer(s)) 2020. No commercial re-use. See rights and permissions. Published by BMJ.

\section{Check for updates}

To cite van der Geest KSM, Dasgupta B. Ann Rheum Dis Epub ahead of print: [please include Day Month Year]. doi:10.1136/annrheumdis-2020-218654

Received 23 July 2020

Accepted 25 July 2020

\section{SLinked}

- http://dx.doi.org/10.1136/annrheumdis-2020-218631

Ann Rheum Dis 2020;0:1. doi:10.1136/annrheumdis-2020-218654

\section{ORCID iDs}

Kornelis SM van der Geest http://orcid.org/0000-0003-2798-6765

Bhaskar Dasgupta http://orcid.org/0000-0002-5523-6534

\section{REFERENCES}

1 Molina Collada J, Martínez-Barrio J, Serrano-Benavente B, et al. Diagnostic value of ultrasound halo count and halo score in giant cell arteritis: a retrospective study from routine care. Ann Rheum Dis 2020. doi: 10.1136/annrheumdis-2020-218631.

2 van der Geest KSM, Borg F, Kayani A, et al. Novel ultrasonographic halo score for giant cell arteritis: assessment of diagnostic accuracy and association with ocular ischaemia. Ann Rheum Dis 2020;79:393-9.

3 van der Geest KS, Borg F, Kayani A, et al. Response to: 'Diagnostic accuracy of novel ultrasonographic halo score for giant cell arteritis: methodological issues' by Ghajari and Sabour. Ann Rheum Dis 2020. doi:10.1136/annrheumdis-2020-218144. [Epub ahead of print: 22 Jun 2020].

4 van der Geest KSM, Dasgupta B. Response to: "Halo Score': missing large vessel giant cell arteritis- do we need a modified 'Halo Score?" by Chattopadhyay and Ghosh. Ann Rheum Dis 2020;36:annrheumdis-2020-218262. 